\title{
ПРИНЦИП ВЕРХОВЕНСТВА ПРАВА ЯК ОСНОВА АДМІНІСТРАТИВНОГО СУДОЧИНСТВА
}

\author{
THE PRINCIPLE OF THE RULE OF LAW \\ AS A BASIS OF ADMINISTRATIVE PROCEDURE
}

Вовк П.В., к.ю.н., докторант

Науково-дослідного інституту публічного права

Актуальність теми підтверджується тим, що сучасний стан нормативного закріплення принципу верховенства права в чинному законодавстві України характеризується недостатньою конкретизацією змісту означеного принципу та основних ознак (критеріїв) його належного дотримання як органами публічної (державної та самоврядної) влади, так і громадянами. Тому, з метою оновлення адміністративного законодавства необхідно комплексно проаналізувати принцип верховенства права як основу адміністративного судочинства. Мета статті полягає в тому, щоб на основі філософії права, теорії адміністративного права і процесу, норм законодавства описати принцип верховенства права як основу адміністративного судочинства. У статті сформовано поняття «принцип верховенства права». Узагальнено, що принцип верховенства права є реальною та невід'ємною основою адміністративного судочинства. Описано, що принцип верховенства права є підґрунтям для дотримання усіх інших принципів адміністративного судочинства, в першу чергу, принципу справедливості як сучасної засади вирішення публічно-правового конфрлікту. Встановлено, що принцип верховенства права включає в себе норми права, судові прецеденти (висновки Верховного суду), стратегії та концепції оновлення адміністративно-процесуального законодавства. 3'ясовано, що принцип верховенства права - це правова субстанція будь-якої правової держави в сучасному світі, що включає в себе механізми, процедури та концепції використання усіх проявів права у діяльність влади, суспільства та окремих осіб з метою правового, соціального, економічного та іншого державного регулювання існуючих, ново утворюючих та майбутніх соціальних відносин. Зроблено висновок, що принцип верховенства права є підірунтям для дотримання усіх інших принципів адміністративного судочинства, в першу чергу, принципу справедливості як сучасної засади вирішення публічно-правового конфрлікту. Тобто, принцип верховенства права як основа адміністративного судочинства - це сукупність ідей, концепцій, механізмів та процедур використання усіх проявів права при вирішенні публічно-правових конфліктів, функціонуванні адміністративних судів та оновленні адміністративно-процесуального законодавства з метою реалізації ефективного, справедливого та незмінного захисту прав, свобод та законних інтересів осіб та суспільства як основної місії правової держави.

Ключові слова: адміністративне судочинство, адміністративний процес, адміністративні суди, захист прав і свобод, парадигма, правова держава, принцип верховенства права, суб'єкти владних повноважень, теорія адміністративного судочинства.

The urgency of the topic is confirmed by the fact that the current state of normative enshrinement of the rule of law in the current legislation of Ukraine is characterized by insufficient specification of the content of this principle and the main features (criteria) of its proper observance by public (state and self-government) and citizens. Therefore, in order to update the administrative legislation, it is necessary to comprehensively analyze the principle of the rule of law as the basis of administrative proceedings. The purpose of the article is to describe the principle of the rule of law as the basis of administrative proceedings on the basis of philosophy of law, theory of administrative law and process, norms of legislation. The article forms the concept of "principle of the rule of law". It is generalized that the principle of the rule of law is a real and integral basis of administrative proceedings. It is described that the principle of the rule of law is the basis for compliance with all other principles of administrative justice, first of all, the principle of justice as a modern basis for resolving public-law conflict. It is established that the principle of the rule of law includes the rules of law, judicial precedents (Supreme Court conclusions), strategies and concepts for updating administrative procedure legislation. It was found that the principle of the rule of law is the legal substance of any state governed by the rule of law in the modern world which includes mechanisms, procedures and concepts for using all manifestations of law in government, society and individuals for legal, social, economic and economic purposes other state regulation of existing, newly formed and future social relations. It is concluded that the principle of the rule of law is the basis for compliance with all other principles of administrative justice, first of all, the principle of justice as a modern basis for resolving public-law conflict. That is, the principle of the rule of law as the basis of administrative justice is a set of ideas, concepts, mechanisms and procedures for using all manifestations of law in resolving public conflicts, functioning of administrative courts and updating administrative procedure legislation to implement effective, fair and consistent protection of rights freedoms and legitimate interests of individuals and society as the main mission of the rule of law.

Key words: administrative courts, administrative justice, administrative process, constitutional state, paradigm, protection of rights and freedoms, subjects of authority, rule of law, theory of administrative justice.

Актуальність теми. Сучасний стан нормативного закріплення принципу верховенства права в чинному законодавстві України характеризується недостатньою конкретизацією змісту означеного принципу та основних ознак (критеріїв) його належного дотримання як органами публічної (державної та самоврядної) влади, так і громадянами. Необхідно переглянути законодавчі акти України, що визначають основні засади діяльності органів державної влади, врахувавши принаймні істотні вимоги дотримання принципу верховенства права [7, с. 33-43].

Запровадження в національному адміністративному законодавстві оновлених доктринальних засад розуміння принципу верховенства права 3 урахуванням положень сучасних західних європейських правових доктрин створить необхідні передумови для приведення базових засад діяльності органів публічної адміністрації - інституту, що тільки розвивається в Україні, - у відповідність до уніфікованих провідними європейськими регіональними організаціями принципів і стандартів публічної адміністрації та урядування [7, с. 33-43].
Таким чином, 3 метою оновлення адміністративного законодавства необхідно комплексно проаналізувати принцип верховенства права як основу адміністративного судочинства.

Стан дослідження. До сутності принципу верховенства права як основи адміністративного судочинства звертали свою увагу чисельні вітчизняні вчені, серед них: В. Авер'янов, О. Бандурка, О. Бачеріков, В. Бевзенко, В. Галунько, Л. Глущенко, О. Дубенко, А. Іванищук, В. Кравчук, О. Кузьменко, Р. Кузьмін, О. Міщенко, С. Потапенко, А. Руденко, Я. Рябченко, М. Сорока, С. Стеценко, О. Умнова, Е. Швед, Н. Шевцова, О. Яцун та ін. Проте, враховуючи ступінь важливості аналізованого питання, дана проблематика є беззаперечно актуальною.

Мета статті полягає в тому, щоб на основі філософії права, теорії адміністративного права і процесу, норм законодавства описати принцип верховенства права як основу адміністративного судочинства.

Викладення основних положень. Відповідно до Кодексу адміністративного судочинства України суд при вирішенні 
справи керується принципом верховенства права, відповідно до якого, зокрема, людина, ії права та свободи визнаються найвищими цінностями та визначають зміст і спрямованість діяльності держави. Суд застосовує принцип верховенства права з урахуванням судової практики Свропейського суду $з$ прав людини. Звернення до адміністративного суду для захисту прав і свобод людини і громадянина безпосередньо на підставі Конституції України гарантується. Забороняється відмова в розгляді та вирішенні адміністративної справи 3 мотивів неповноти, неясності, суперечливості чи відсутності законодавства, яке регулює спірні відносини [3]. Наведене формулювання вказує на те, що дотримання прав людини є складовою принципу верховенства права, а також на те, що ця складова не є єдиною. Однак принцип законності винесено за межі принципу верховенства права у ст. 7 КАСУ, так само як рівність перед законом і судом - у ст. 10 КАСУ, тоді як вони є складовими принципу верховенства права [10, с. 170-175].

В українському правознавстві $є$ чимало спроб подати принцип верховенства закону як базовий принцип правового розвитку. На погляд М. Братасюк, в нинішніх умовах при побудові демократичних засад життя складовою верховенства права має бути не просто принцип законності, який у випадку прийняття неправових, наприклад, замовлених законів, що втілюють примхи влади, сприяє порушенню прав людини, знищенню права як справедливості, а принцип правової законності, тобто принцип, який стверджує панування законів, змістовно наповнених правовими смислами. Такі закони справедливо виражають співвідношення інтересів суб'єктів права, в т. ч. і держави, мають моральний зміст, працюють на спільне благо країни і людей [2, с. 11].

Принцип верховенства права, з позиції Р. Кузьміна, не слід протиставляти верховенству закону. Принцип верховенства права (rule of law), на переконання вченого, насправді $є$ утвердженням правлячої сили закону, противагою, антиподом так званого «ручного» управління. Правити має закон. Загальновідомо, що управління за допомогою закону і демократичніше, і більш об'єктивне, i економніше (одна норма права замінюе тисячі індивідуальних велінь ... і лише турбота про застосування залишається ... - говорив ще Р. Ієрінг), порівняно 3 "ручним» - суб'єктивістським за своєю суттю управлінням. Верховенство права включає забезпечення законності, неухильне дотримання законів [4, с. 5-12].

Тобто, принцип верховенства права $є$ значно ширшим за принцип законності, оскільки перший включає у себе усі легітимні прояви права, а не лише унормовані та визначені державою закони.

Розуміння сучасного значення та обсягу змісту принципу верховенства права як правового явища розкриває логічні взаємозв'язки між малодослідженими вітчизняною адміністративно-правовою наукою поняттями «належної адміністрації» (англ. «good administration») та «належного урядування» (англ. «good governance») [7, с. 33-43].

Конституційні принципи, принципи права загалом i, передусім, принцип верховенства права служать своєрідними основоположними засадами, провідними ідеями, що мають пронизувати всю державну політику України. Вони спрямовують іiі розвиток у відповідне русло, визначають пріоритети цієї політики, працюють на суспільну злагоду, гармонізацію інтересів різних соціальних груп тощо. Порушення системи конституційних принципів як фундаментальних, базових засад будь-якої державної політики може спричинити ï цілковиту руйнацію, що, безумовно, чинитиме негативний вплив на весь суспільний організм. Необхідно також зміцнити й активізувати українське громадянське суспільство, що сприятиме прозорості та відповідальності влади, захисту прав вразливих груп, зокрема людей з особливими потребами, затриманих й ув'язнених осіб, а також жінок і молоді тощо [8, с. 77].
Верховенство права, як переконує Р. Кузьмін, це коли закони не тільки справедливі, а й відповідно до них живуть усі. Тобто вони є однаково обов'язковими для двірника, будь якого чиновника, включаючи Президента країни. Такий підхід не тільки ставить все на свої місця, усуваючи протиріччя між правом і законністю, між принципами верховенства права і законності, а й має конструктивну спрямованість, вихід на постановку завдання розробки і прийняття справедливих, суспільно корисних законодавчих актів. Таким чином, верховенство права - це і правління закону (правління винятково за допомогою законів), i забезпечення справедливості законів, і неухильне їх дотримання [4, с. 5-12].

Як саме право, так і його верховенство у суспільстві і державі, В. Шатіло розглядає у двох аспектах. По-перше, принцип верховенства права слід визначати 3 позиції філософсько-етичного, світоглядного, легітимаційного підходу до права, згідно з яким право - це усіма визнана міра свободи, що відповідає вимогам загальнолюдської моралі, рівності і справедливості в суспільстві, міжнародним стандартам у галузі прав людини. По-друге, принцип верховенства права треба розглядати з позицій формально-легального (позитивістського) підходу до права, згідно з яким право - це система нормативних настанов (норм права), встановлених державою (відповідними державними органами) для регулювання суспільних відносин. Принцип верховенства права, який проголошує і закріплює Конституція України і який є найважливішою ознакою правової держави, об'єднує ці два підходи у єдине ціле. Він зобов'язує розглядати право як одну найголовніших соціальних цінностей саме тому, що воно домінує у державі, суспільстві порівняно з іншими цінностями, які сповідує людина: звичаями, особистими переконаннями, уподобаннями і таке інше. 3 іншого боку, над нормами права височать норми вищої регулятивної сили, що підсилюють легалістичну складову правової держави легітимаційною складовою (моральні, релігійні, ідеологічні) і є складовими міжнародного права. Тим самим правова держава набуває ознак соціалізованості і перестає бути просто формальним інструментом забезпечення правопорядку [9, с. 40].

На підставі аналізу чинного законодавства України А. Пухтецька, виділила такі основні підходи до текстуального закріплення принципу верховенства права: а) визначення принципу верховенства права як складника курсу, політики держави або як суспільної цінності; б) розгляд принципу верховенства права як принципу діяльності державного органу, його посадових осіб, основи організації державного управління в певній сфері; в) фіксація принципу верховенства права як одного з основних міжнародно-правових принципів та беззастережного пріоритету, одного з основних стандартів РЄ, як орієнтира роботи центральних органів виконавчої влади з виконання зобов'язань України перед СС і РС, іншими міжнародними та регіональними організаціями щодо забезпечення стабільності та ефективності функціонування інститутів, які гарантують демократію, верховенства права, дотримання прав людини; г) розгляд принципу верховенства права як принципу здійснення судочинства i водночас завдання подальшого розвитку правосуддя, реалізації судової реформи; г) виокремлення принципу верховенства права як складника в назві державного органу, посади, програми, законодавчого акта [7, с. 33-43].

Складовими принципу, означеного як «the rule of law», відповідно до концепції А. Дайсі були: - «верховенство права» як протиставлення кожній системі державної влади, в основі якої лежать дії свавільного характеру (заперечення свавільної влади), з тим, щоб виключити для влади загалом та іiї посадових осіб зокрема можливість діяти інакше, ніж на підставі повноважень, визначених приписами права; - «верховенство права» як рівність 
усіх членів суспільства перед законом, де виключено ідею будь-якого звільнення посадових осіб від відповідальності за свої дії та передбачено поширення на посадових осіб такої ж рівної дії законів і такої ж юрисдикції звичайних судів, як і на простих громадян; - «верховенство права» як верховенство духу права, яке означає, що свободи людини не $є$ наслідком проголошених в офіційному документі (писаній конституції) гарантій, а навпаки - сама конституція в англійському суспільстві є наслідком прав особи, бо ці права існували ще до виникнення і закріплення положень права, що складають конституцію, а свій конкретний зміст ці положення дістали в результаті витлумачення суддями сутності цих прав упродовж тривалого процесу розгляду конкретних справ у звичайних судах. Сформульовані А. Дайсі теоретичні положення принципу верховенства права - це концентрований вираз ідей, концепцій, теорій, конструкцій та формул, напрацьованих упродовж багатьох віків [11; 12, с. 161; 5, с. 62-67].

Зміст принципу верховенства права в діяльності публічних адміністрацій, з позиції В. Полубатко слід охарактеризувати як правовий принцип, який характеризується сукупністю обов'язкових критеріїв (вимог), що покликані насамперед забезпечувати пріоритет прав і свобод, законних інтересів людини і громадянина у суспільстві, в тому числі у взаємостосунках з органами публічної адміністрації усіх рівнів. До цієї сукупності критеріїв (вимог) необхідно відносити зазвичай принципи рівності суб'єктів права перед законом, верховенства закону в системі актів законодавства країни, забезпечення якості закону, його підпорядкування конституційно-правовим нормам, загальним принципам права, міжнародним договорам і угодам, а також включити до цього переліку вимоги щодо передбачуваності законів та дій органів державної влади, встановлення меж дискреційних повноважень та вимог щодо обмеження свавілля органів публічної влади, юридично визначеності, ефективного контролю за реалізацією прав і основоположних свобод людини, пропорційності, гарантованості мінімального ступеня захисту, доступу до суду та справедливого судового розгляду та деякі інші вимоги, що визнаються істотними елементами принципу верховенства права в європейській правозастосовній практиці, насамперед у рішеннях ЄСПЛ, та порушення яких навіть у період війни або іншої суспільної небезпеки є неприпустимим. Інститут верховенства права в діяльності публічних адміністрацій - це старий для європейських країн, проте відносно новий і багато в чому унікальний інститут для нашої держави, застосування якого в Україні має бути ретельно вивчене. Він, безперечно, має цілу низку переваг, проте слід усвідомлювати, що чиновницький апарат здійснюватиме спротив його масовому та комплексному уведенню в дію. Тому, на думку В. Полубатко, слід зосередитися на дослідженні того, як отримати від інституту верховенства права в діяльності публічних адміністрацій якнайбільше переваг для пересічного громадянина та системи громадянського суспільства у цілому, водночас запобігши зловживанням, які можуть мати місце під час його уведення в дію [6, с. 323-327].

Таким чином, принцип верховенства права - це правова субстанція будь-якої правової держави в сучасному світі, що включає в себе механізми, процедури та концепції використання усіх проявів права у діяльність влади, суспільства та окремих осіб з метою правового, соціального, економічного та іншого державного регулювання існуючих, ново утворюючих та майбутніх соціальних відносин.

Міркуючи про дію й застосування принципу верховенства права в національному адміністративному судочинстві, В. Бевзенко вважає, що по-перше, що при здійсненні правосуддя в адміністративних справах насамперед слід керуватися принципом верховенства, який, на жаль, не враховується суддями, поза їх увагою лишається критерій справедливості, як спосіб належного вирішення публічно-правової суперечки. По-друге, навіть за умови виконання приписів норм Кодексу адміністративного судочинства України, у вітчизняній судовій практиці допускається бюрократія і формалізм, що значно перешкоджає захисту суб'єктивних прав, свобод, законних інтересів публічного змісту. Тому про існування в Україні ефективних засобів юридичного захисту в національному органі, навіть якщо таке порушення було вчинене особами, які здійснювали свої офіційні повноваження, говорити не доводиться. По-третє, в Україні відсутній правовий механізм ефективного поновлення прав кожної людини у правах компетентними національними судами в разі порушення іiї основних прав, наданих їй конституцією або законом. По-четверте, Україна не дотримується взятих на себе зобов'язань, зокрема щодо забезпечення будь-якій особі, права і свободи якої, визнані європейським правом, порушено, ефективного засобу правового захисту, навіть коли це порушення було вчинене особами, що діяли як особи офіційні; забезпечити, щоб право на правовий захист для будь-якої особи, яка потребує такого захисту, встановлювалось компетентними судовими, адміністративними чи законодавчими властями або будь-яким іншим компетентним органом, передбаченим правовою системою держави, і розвивати можливості судового захисту [1, с. 40-44].

Щодо принципу верховенства права і справедливості законів, тут, з позиції Р. Кузьміна, мається на увазі використання його у правотворчості. Принцип верховенства права, на нашу думку, передбачає управління на основі не будь-якого закону, а закону правового, тобто справедливого, суспільно корисного. Відповідно до висновків теорії права є закони правові, тобто ті, які справедливі, суспільно корисні, і неправові - не відповідають вимогам справедливості, суспільної корисності. Завдання судочинства (у рамках принципів законності і верховенства права) - це, по-перше, контроль за відповідністю дій відповідача (підсудного) чинним законам та прийняття судового рішення із захисту прав, свобод та законних інтересів людини і громадянина, прав та законних інтересів юридичних осіб, інтересів держави. По-друге, це внутрішня оцінка суддею справедливості закону чи іншого правового акта, критерієм якої є відповідність його Конституції України. У разі виникнення в суду сумніву під час розгляду справи щодо відповідності закону чи іншого правового акта Конституції України, вирішення питання про конституційність якого належить до юрисдикції Конституційного Суду України, суд, як зазначається у вище цитованій ст. 9 КАС України, звертається до Верховного Суду України для вирішення питання стосовно внесення до Конституційного Суду України подання щодо конституційності закону чи іншого правового акта. На стадії правотворчості, розробки, експортування, прийняття проектів нормативно-правових документів розробники, експерти, особи, які обговорюють і приймають відповідні акти, мають оцінювати їх справедливість, керуючись і Конституцією, і європейськими нормами, і власною совістю [3; 4, с. 5-12].

Висновки. Таким чином, аналізуючи позиції деяких вчених щодо використання верховенства права в площині адміністративного судочинства, можна узагальнити, що принцип верховенства права $є$ реальною та невід'ємною основою адміністративного судочинства.

Принцип верховенства права є підгрунтям для дотримання усіх інших принципів адміністративного судочинства, в першу чергу, принципу справедливості як сучасної засади вирішення публічно-правового конфлікту.

Принцип верховенства права включає в себе як норми права, але також судові прецеденти (висновки Верховного суду), а також стратегії та концепції оновлення адміністративно-процесуального законодавства. 
Тобто, принцип верховенства права як основа адміністративного судочинства - це сукупність ідей, концепцій, механізмів та процедур використання усіх проявів права при вирішенні публічно-правових конфліктів, функціонуванні адміністра- тивних судів та оновленні адміністративно-процесуального законодавства 3 метою реалізації ефективного, справедливого та незмінного захисту прав, свобод та законних інтересів осіб та суспільства як основної місії правової держави.

\section{ЛITEPATУPA}

1. Бевзенко В. М. Міркування про дію й застосування принципу верховенства права в національному адміністративному судочинстві. Форум права. 2011. № 2. С. 40-44.

2. Братасюк М. Г. Співвідношення принципу верховенства права та принципу законності. Актуальні проблеми правознавства. 2018. Вип. 1. С. 11-17.

3. Кодекс адміністративного судочинства України. Відомості Верховної Ради України. 2005. № 35-36, № 37. Ст. 446.

4. Кузьмін Р. Складові принципу верховенства права. Вісник Національної академії прокуратури України. 2011. № 1. С. 5-12.

5. Малютін І. А. Розвиток принципу верховенства права в контексті доктрини природного права. Адміністративне судочинство. 2012. № 3-4. C. 61-68.

6. Полубатко В.В.Принцип верховенства права у правозастосовній діяльності публічної адміністрації. Часопис Київського університету права. 2017. № 2. С. 323-327.

7. Пухтецька А. Принцип верховенства права: сучасні європейські доктрини як орієнтир для реформування національного законодавства. Вісник Національної академії наук України. 2010. № 3. С. 33-43.

8. Росоляк О. Б. Принцип верховенства права як засада державного управління. Юридичний часопис Національної академії внутрішніх справ. 2012. № 1(3). С. 71-77.

9. Шатіло В. Концептуальна генеза правової держави та ї̈ вплив на формування загальних принципів державної влади в Україні. Вісник Київського національного університету імені Тараса Шевченка. Юридичні науки. 2013. Вип. 95. С. 37-40.

10. Шульга $€$. В. Роль та значення принципу верховенства права в адміністративно-деліктних відносинах. Актуальні проблеми правознавства. 2017. Вип. 4. С. 170-175.

11. Dicey A. V. Introduction to the Study of the Law of the Constitution. 10 th ed., 1959 / with introd. by E. C. S. Wade. London ; New York, 1961.

12. Dicey A. V. Lectures Introductory to the Study of the Law of the Constitution. London, 1885. 